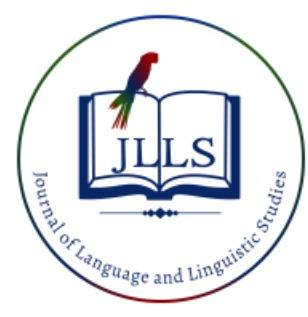

Available online at www.jlls.org

JOURNAL OF LANGUAGE AND LINGUISTIC STUDIES

ISSN: 1305-578X

Journal of Language and Linguistic Studies, 16(3), 1352-1367; 2020

\title{
Foreign language learning effort levels of students in English for specific purposes
}

\author{
Selda Özer ${ }^{\text {a }}$ iD
}

${ }^{a}$ Nevşehir Hacı Bektaş Veli University, Nevşehir, Turkey

\section{APA Citation:}

Özer, S. (2020). Foreign language learning effort levels of students in English for Specific Purposes. Journal of Language and Linguistic Studies, 16(3), 1352-1367.

Submission Date: 30/04/2020

Acceptance Date: 01/07/2020

\begin{abstract}
The study aims to investigate foreign language learning effort levels of students in English for Specific Purposes. In the study, quantitative research and survey method were applied. 385 students studying at a faculty of tourism and taking vocational English course at a state university in Turkey participated in the study voluntarily. Foreign Language Learning Effort Scale (FLLES) was used to collect data. At the end of the study, the students' level of non-compliance was at "never" level, their procedural, focal and overall effort levels were at "often" level and their substantive effort level was at "sometimes" level. While there was no significant difference in noncompliance and overall effort levels of the students, there was a significant difference in their procedural, substantive and focal effort levels in terms of their gender and age. There was no significant difference in noncompliance, procedural, substantive and overall effort levels of the students but there was a significant difference in their focal effort levels in terms of their education type. There was not a significant difference in noncompliance, procedural and substantive effort levels of the students; however, there was a significant difference in their focal and overall language learning effort levels in terms of their department. There was a significant difference in non-compliance, procedural, substantive, focal and overall language learning effort levels of the students in terms of their achievement.
\end{abstract}

C) 2020 JLLS and the Authors - Published by JLLS.

Keywords: foreign language learning effort; English for Specific Purposes; vocational English course; tourism

\section{Introduction}

Learning effort of students has always been considered as an essential component in education for educators, students, educational scholars/researchers and even for parents in that it is an internal structure and controllable among all the factors believed to promote educational outcomes. Learning effort can simply imply the mental exertion or willingness to insist on accomplishing a task. Attending classes, participating in the classes, doing classroom tasks and homework assignments have been

\footnotetext{
${ }^{1}$ Selda Özer. Tel.: +90-505-253-8444

E-mail address: sozer@nevsehir.edu.tr
} 
regarded as indicators of learning effort. However, it is initially important to examine learning effort defined in the literature.

Zimmerman and Risenberg (1997) defined learning effort as "the overall amount of energy spent in the process of studying", while Carbonaro (2005) defined "the amount of time and energy that students expend in meeting formal academic requirements established by their teacher and/or school". In educational studies, the degree of effort is also taken into consideration Agbuga and Xiang (2008) described the degree of effort as "overall amount of energy or work expended over the course of learning". In addition, the quality of the time spent is much more important than the quantity when learning effort is taken into consideration (Didia \& Hasnat, 1998).

Learning effort is divided into three categories by Carbonaro (2005) as rule-oriented, procedural, and intellectual. Rule oriented effort involves attending the classes and behaving appropriately and it indicates compliance to the norms and rules of the classroom and school. Procedural effort involves meeting specific class requirements and it indicates participating actively in classes, completing assignments and submitting them on time. Intellectual effort involves thinking about and understanding the curriculum or course content critically and it indicates spending time and energy for studying and reviewing (Carbonaro, 2005).

On the other hand, Bozick and Dempsey (2010) divided learning effort into three as procedural, substantive, and non-compliance. Procedural effort involves completing tasks, acting upon school and classroom rules, and spending the minimal amount of effort necessary for functioning and advancing in school and it indicates homework completion, in-class attentiveness and punctuality. Substantive effort involves active involvement in learning and it indicates spending extra time to prepare or study for exams as well as working hard at school. Non-compliance involves behaviors preventing learning effort and it indicates misbehaviors such as not completing homework, coming late to class and daydreaming in class (Bozick \& Dempsey, 2010).

Foreign language learning effort can be defined as the investment of individual resources by students to learn a foreign language including in-class and out-of-class exertions and engaging students to fulfill the process of learning a foreign language (Karabiyık \& Mirici, 2018). Learning effort is a multifaceted construct within the context of foreign language learning. Therefore, in the study, four dimensions of learning effort were taken into consideration as non-compliance, procedural effort, substantive effort, and focal effort. Non-compliance involves behaviors that hinder exerting effort in a foreign language classroom. Procedural effort involves endeavors for fulfilling the requirements specific to a foreign language classroom. Substantive effort refers to active involvement in learning a foreign language. Focal effort implies attentiveness in a foreign language classroom (Karabıyık \& Mirici, 2018).

When the literature was reviewed, it was observed that foreign language learning effort was generally examined as an output regarding generally motivation (Al Shaye et al., 2014; Dörnyei, 2005) or attitude (Hemmings \& Kay, 2010). However, the literature lacks the studies scrutinizing foreign language learning effort itself. In addition, effort was usually examined as the number of hours spent outside the classroom (Özer, 2019a; Aratibel \& Bueno-Alastuey, 2015; Inagaki, 2014; Opare \& Dramanu, 2002). As Yeung and McInerney (2005) pointed out, effort put forth in learning a foreign language was one of the most crucial contributors of achievement. Consequently, the aim of the study is to investigate foreign language learning effort levels of students in the context of English for Specific Purposes. In line with this aim, the study asks the following questions:

1. What are the levels of foreign language learning effort of students in terms of non-compliance, procedural, substantive, focal and overall effort?

2. Do students' non-compliance, procedural, substantive, focal and overall language learning effort levels differ in terms of 
their gender?

their age?

their education type?

their departments?

their achievement in vocational English course?

\section{Method}

Survey methodology and quantitative research design were applied in the study. Survey methodology is generally defined as "a research model aiming to examine a situation as it exists in the nature" (Karasar, 2003). The study aimed at analyzing the levels of foreign language learning effort of students studying at a faculty of tourism in their own context.

\section{1. Participants}

The current study was held in a faculty of tourism at a state university in Turkey. The study included all students studying at the faculty and taking vocational English course in 2018-2019 spring semester. Junior and senior students take vocational English course at the faculty, thus junior and senior students participated in the study. A total of 385 participated in the study voluntarily and gave consent to collect data. Table 1 displayed demographic features of the students.

Table1. Demographic features of the students

\begin{tabular}{llcc}
\hline Demographic features & & $\mathrm{f}$ & $\%$ \\
\hline \multirow{2}{*}{ Gender } & Female & 163 & 42.3 \\
& Male & 222 & 57.7 \\
\hline \multirow{2}{*}{ Age } & 20-23 years old & 217 & 56.4 \\
& 24 and older & 168 & 43.6 \\
\hline \multirow{2}{*}{ Education type } & Daytime & 303 & 78.7 \\
& Evening & 82 & 21.3 \\
\hline \multirow{3}{*}{ Department } & Tourism Management & 231 & 60.0 \\
& Tourism Guidance & 52 & 13.5 \\
& Gastronomy and Culinary Arts & 102 & 26.5 \\
\hline \multirow{3}{*}{ Achievement } & 1 low (DC-DD-DF-FF) & 42 & 10.9 \\
& 2 mid (BB-CB-CC) & 267 & 69.4 \\
& 3 high (AA-BA) & 76 & 19.7 \\
\hline & Total & 385 & 100 \\
\hline
\end{tabular}

\section{2. Instrument}

Foreign Language Learning Effort Scale (FLLES): Foreign Language Learning Effort Scale was developed by Karabiyık and Mirici (2018) to measure the effort levels of tertiary level foreign language learners. The scale comprised of 17 items. It was a five-point Likert scale and graded as "never", "rarely", sometimes", often" and "always". Exploratory factor analysis showed that the scale had four factors named as non-compliance ( 3 items), procedural (3 items), substantial (9 items) and focal (3 items). The students were asked to respond to the items by taking vocational English course into consideration. Confirmatory factor analysis reflected that the fit indices for the 4-factor model were $\chi 2=314.40, \mathrm{df}=.110, \mathrm{RMSEA}=.05, \mathrm{SRMR}=.04, \mathrm{GFI}=.95, \mathrm{AGFI}=.92, \mathrm{CFI}=.95, \mathrm{NFI}=.93, \mathrm{NNFI}=.94$, 
$\mathrm{p}=0.00$. The model fit for 4-factor model was found to be sufficient for the pilot sample. After confirmatory factor analysis, Cronbach's alpha values of the subscales were estimated as $.85, .85, .81$, and .75 for non-compliance, procedural effort, substantive effort, and focal effort, respectively. Cronbach's alpha value for overall scale was .86 for the pilot sample. In addition, the scale was replicated over an independent sample. Confirmatory factor analysis reflected that the fit indices for the 4-factor model were $\chi 2=275.48, \mathrm{df}=.102, \mathrm{RMSEA}=.05, \mathrm{GFI}=.96, \mathrm{CFI}=.96, \mathrm{NNFI}=.95, \mathrm{p}=0.00$. The model fit for 4-factor model was found to display a good fit with the replication sample. After confirmatory factor analysis, Cronbach's alpha values of the subscales were estimated as $.80, .83, .82$, and .77 for non-compliance, procedural effort, substantive effort, and focal effort, respectively. Cronbach's alpha value for overall scale was .85 for the replication sample. (Karabiy1k \& Mirici, 2018). Cronbach's alpha values of the subscales were estimated as $.75, .73, .85$, and .81 for non-compliance, procedural effort, substantive effort, and focal effort, respectively and Cronbach's alpha value for overall scale was .87 in the present study.

\section{3. Data analysis}

The Statistical Package for Social Sciences (SPSS) 22.0. was used to analyze the data in the current study. Prior to analyses of the data, it was checked whether the data were normally distributed. It was found out that the data showed normal distribution. Maximum, minimum, mean and standard deviation scores of four sub-scales and overall scale were determined. Class width formula (class range/number of classes) recommended by Tekin (2002) and used in many studies (Özer, 2019a; Özer, 2019b; Evin Gencel \& Satmaz, 2017; Çavuşoğlu Deveci et al, 2016) was used in the assessment of mean scores. In other words, class width was calculated by the dividing the difference between the highest (5) and lowest score (1) by the number of classes (5). Class width levels used in the evaluation of the research findings are as follows:

1-1.80: "Never",

1.81-2.60: "Rarely",

2.61-3.40: "Sometimes",

3.41-4.20: "Often" and

4.21-5.00: "Always".

Independent-Samples t-test was used to compare two groups, one-way ANOVA was used to compare groups more than two. Tukey test was applied to determine the source of the difference between groups. In addition, the concept of "effect size" has become widely discussed throughout educational literature in recent years, and even it has been used more prevalently in recent studies. As Kotrlik and Williams (2003) recommended, a researcher should provide both the statistical significance test results and an appropriate effect size measure. For Cohen (1988), Cohen's $d$ should be measured to determine the effect size in t-tests, Cohen's $f$ should be measured in oneway ANOVA (Özsoy \& Özsoy, 2013; Kotrlik $\&$ Williams, 2003; Cohen, 1988). As independent samples t-test and one-way ANOVA analyses were applied in the present study to examine mean differences, Cohen's $d$ and Cohen's $f$ were measured to determine the effect size, respectively. The effect size is considered to be small if $d$ is .20, medium if $d$ is .50, and large if $d$ is .80. The effect size is considered to be small if $f$ is .10, medium if $f$ is .25 , and large if $f$ is .40 (Işık, 2014; Kotrlik \& Williams, 2003; Cohen, 1988). 


\section{Results}

Mean, standard deviation, maximum and minimum scores of four sub-scales (non-compliance, procedural, substantive, focal) and the overall scale were measured and given in Table 2, Table 3, Table 4, Table 5 and Table 6 , respectively.

Table 2. Non-compliance levels of the students

\begin{tabular}{lllllll}
\hline Items & $\mathrm{N}$ & Min. & Max. & X & S.D. & Level \\
\hline 2. I engage in disruptive behaviors in classes. & 385 & 1.00 & 5.00 & 1.61 & 1.09 & Never \\
8. I cheat on exams. & 385 & 1.00 & 5.00 & 1.34 & .81 & Never \\
14. I plagiarize my homework assignments. & 385 & 1.00 & 5.00 & 1.36 & .82 & Never \\
\hline Non-compliance & 385 & 1.00 & 4.67 & 1.43 & .74 & Never \\
\hline
\end{tabular}

When Table 2 was examined, it was observed that the students' mean score for non-compliance was 1.43 and it was at "never" level. The students declared that they never engage in disruptive behaviors in classes $(X=1.61)$, plagiarize their homework assignments $(X=1.36)$ and cheat on exams $(X=1.34)$.

Table 3. Procedural effort levels of the students

\begin{tabular}{lllllll}
\hline Items & $\mathrm{N}$ & Min. & Max. & $\mathrm{X}$ & S.D. & Level \\
\hline 4. I do my homework on time. & 385 & 1.00 & 5.00 & 3.17 & 1.23 & Sometimes \\
10. I submit my homework on time. & 385 & 1.00 & 5.00 & 3.76 & 1.28 & Often \\
16. I carry out the assigned in-class tasks. & 385 & 1.00 & 5.00 & 3.44 & 1.22 & Often \\
\hline Procedural effort & 385 & 1.00 & 5.00 & 3.45 & 1.00 & Often \\
\hline
\end{tabular}

As seen in Table 3, the students' mean score for procedural effort was 3.45 and it was at "often" level. They reported that they often submit their homework on time $(X=3.76)$ and carry out the assigned in-class tasks $(\mathrm{X}=3.44)$. The students also expressed that they sometimes do their homework on time $(\mathrm{X}=3.17)$.

Table 4. Substantive effort levels of the students

\begin{tabular}{|c|c|c|c|c|c|c|}
\hline Items & $\mathrm{N}$ & Min. & Max. & $\mathrm{X}$ & S.D. & Level \\
\hline 1. I prepare well for my foreign language exams. & 385 & 1.00 & 5.00 & 3.52 & 1.13 & Often \\
\hline 3. I review the topics covered in my foreign language class. & 385 & 1.00 & 5.00 & 2.77 & 1.09 & Sometimes \\
\hline 5. I review the topics to be covered in my class. & 385 & 1.00 & 5.00 & 2.38 & 1.11 & Rarely \\
\hline $\begin{array}{l}\text { 7. Even if I am not given a homework assignment I practice } \\
\text { from various sources. }\end{array}$ & 385 & 1.00 & 5.00 & 2.61 & 1.27 & Sometimes \\
\hline $\begin{array}{l}\text { 9. I engage in foreign language mediums in out-of-class } \\
\text { activities (e.g. read books, watch movies, speak to } \\
\text { foreigners, etc.) }\end{array}$ & 385 & 1.00 & 5.00 & 3.30 & 1.43 & Sometimes \\
\hline 11. I revise my assignments if I receive any corrections. & 385 & 1.00 & 5.00 & 3.58 & 1.20 & Often \\
\hline $\begin{array}{l}\text { 13. I consult my foreign language instructor or other experts } \\
\text { for advice on how to improve my English. }\end{array}$ & 385 & 1.00 & 5.00 & 3.46 & 1.12 & Often \\
\hline 15. If possible, I volunteer for extra homework assignments. & 385 & 1.00 & 5.00 & 2.51 & 1.31 & Rarely \\
\hline Substantive effort & 385 & 1.13 & 4.88 & 3.01 & .84 & Sometimes \\
\hline
\end{tabular}

Table 4 displayed that the students' mean score for substantive effort was 3.01 and it was at "sometimes" level. The students stated that they often revise their assignments if they receive any corrections $(X=3.58)$, prepare well for their foreign language exams $(X=3.52)$ and consult their foreign language instructor or other experts for advice on how to improve their English $(X=3.46)$. They reported that they sometimes engage in foreign language mediums in out-of-class activities $(X=3.30)$, review the topics covered in their foreign language class $(X=2.77)$, practice from various sources even if they are 
not given a homework assignment $(X=2.61)$. They also expressed that they rarely volunteer for extra homework assignments if possible $(X=2.51)$ and review the topics to be covered in their class $(X=2.38)$.

Table 5. Focal effort levels of the students

\begin{tabular}{lllllll}
\hline Items & $\mathrm{N}$ & Min. & Max. & X & S.D. & Level \\
\hline 6. I attentively listen to my instructor. & 385 & 1.00 & 5.00 & 3.87 & 1.01 & Often \\
12. I attentively listen to the contributions made by my peers. & 385 & 1.00 & 5.00 & 3.63 & 1.21 & Often \\
17. I concentrate solely on the lesson in my classes. & 385 & 1.00 & 5.00 & 3.88 & 1.08 & Often \\
\hline Focal effort & 385 & 1.53 & 5.00 & 3.78 & .94 & Often \\
\hline
\end{tabular}

Table 5 indicated that the students' mean score for focal effort was 3.78 and it was at "often" level. The students stated that they often concentrate solely on the lesson in their classes ( $X=3.88)$, attentively listen to their instructor $(X=3.87)$ and attentively listen to the contributions made by their peers $(\mathrm{X}=3.63)$.

Table 6. Overall foreign language learning effort levels of the students

\begin{tabular}{lllllll}
\hline & $\mathrm{N}$ & Min. & Max. & $\mathrm{X}$ & S.D. & Level \\
\hline Overall foreign language learning effort & 385 & 1.53 & 5.00 & 3.69 & 1.07 & Often \\
\hline
\end{tabular}

Table 6 showed that the students' mean score for overall foreign language learning effort was 3.69 and it was at "often" level.

Table 7 reflected the result of independent samples t-test to determine whether students' noncompliance, procedural, substantive, focal and overall language learning effort levels differed in terms of their gender.

Table 7. Independent samples t-test results for non-compliance, procedural, substantive, focal and overall language learning effort levels in terms of gender

\begin{tabular}{|c|c|c|c|c|c|c|c|}
\hline & Gender & $\mathrm{N}$ & $X$ & $\mathrm{Sd}$ & $\mathrm{t}$ & $\mathrm{p}$ & $\begin{array}{l}\text { Effect size } \\
\text { (Cohen's } d \text { ) }\end{array}$ \\
\hline \multirow{2}{*}{ Non-compliance } & Female & 163 & 1.49 & .83 & \multirow{2}{*}{1.44} & \multirow{2}{*}{.14} & \multirow{2}{*}{.15} \\
\hline & Male & 222 & 1.38 & .67 & & & \\
\hline \multirow{2}{*}{ Procedural effort } & Female & 163 & 3.58 & 1.02 & \multirow{2}{*}{2.23} & \multirow{2}{*}{$.02 *$} & \multirow{2}{*}{.22} \\
\hline & Male & 222 & 3.35 & .98 & & & \\
\hline \multirow{2}{*}{ Substantive effort } & Female & 163 & 3.26 & .88 & \multirow{2}{*}{5.13} & \multirow{2}{*}{$.00 *$} & \multirow{2}{*}{.52} \\
\hline & Male & 222 & 2.83 & .77 & & & \\
\hline \multirow{2}{*}{ Focal effort } & Female & 163 & 3.91 & 1.02 & \multirow{2}{*}{2.30} & \multirow{2}{*}{$.02 *$} & \multirow{2}{*}{.23} \\
\hline & Male & 222 & 3.69 & .87 & & & \\
\hline \multirow{2}{*}{ Overall effort } & Female & 163 & 3.81 & 1.07 & \multirow{2}{*}{1.84} & \multirow{2}{*}{.06} & \multirow{2}{*}{.19} \\
\hline & Male & 222 & 3.61 & 1.07 & & & \\
\hline
\end{tabular}

*p<.05

As indicated in Table 7, there was no significant difference in the students' non-compliance ( $\mathrm{p}=.14$; $p>.05)$ and overall effort ( $=.06 ; p>.05)$ of students in terms of gender but female students had had a higher mean score than male students. Cohen's $d$ was .15 for non-compliance and .19 for overall language learning effort, which implied a small effect size. There was a significant difference in procedural effort ( $\mathrm{p}=.02 ; \mathrm{p}<.05)$, in substantive effort $(\mathrm{p}=.00 ; \mathrm{p}<.05)$, and in focal effort $(\mathrm{p}=.02 ; \mathrm{p}<.05)$. For procedural effort, female students $(X=3.58)$ had a higher mean score than male students $(X=3.35)$, and thus, female students made more procedural effort than male students. Nonetheless, Cohen's $d$ was .22 and had a small effect size. For substantive effort, female students $(X=3.26)$ had a higher mean score than male students $(X=2.83)$, and thus, female students made more substantive effort than male students. In addition, Cohen's $d$ was .52 and had a medium effect size. For focal effort, female students 
$(X=3.91)$ had a higher mean score than male students $(X=3.69)$, and thus, female students made more focal effort than male students. However, Cohen's $d$ was .23 and had a small effect size.

Table 8 showed the result of independent samples t-test to determine whether students' noncompliance, procedural, substantive, focal and overall language learning effort levels differed in terms of their age.

Table 8. Independent samples t-test results for non-compliance, procedural, substantive, focal and overall language learning effort levels in terms of age

\begin{tabular}{|c|c|c|c|c|c|c|c|}
\hline & Age & $\mathrm{N}$ & $X$ & $\mathrm{Sd}$ & $\mathrm{t}$ & $\mathrm{p}$ & $\begin{array}{c}\text { Effect size } \\
\text { (Cohen's } d \text { ) }\end{array}$ \\
\hline \multirow{2}{*}{ Non-compliance } & $20-23$ years old & 217 & 1.45 & .76 & \multirow[b]{2}{*}{.68} & \multirow[b]{2}{*}{.49} & \multirow{2}{*}{.07} \\
\hline & 24 and older & 168 & 1.40 & .72 & & & \\
\hline \multirow{2}{*}{ Procedural effort } & $20-23$ years old & 217 & 3.27 & 1.00 & \multirow{2}{*}{-4.07} & \multirow{2}{*}{$.00 *$} & \multirow{2}{*}{.48} \\
\hline & 24 and older & 168 & 3.68 & .96 & & & \\
\hline \multirow{2}{*}{ Substantive effort } & 20-23 years old & 217 & 2.86 & .85 & \multirow{2}{*}{-4.16} & \multirow{2}{*}{$.00 *$} & \multirow{2}{*}{.43} \\
\hline & 24 and older & 168 & 3.21 & .79 & & & \\
\hline \multirow{2}{*}{ Focal effort } & 20-23 years old & 217 & 3.60 & .94 & \multirow{2}{*}{-4.27} & \multirow{2}{*}{$.00 *$} & \multirow{2}{*}{.45} \\
\hline & 24 and older & 168 & 4.01 & .90 & & & \\
\hline \multirow{2}{*}{ Overall effort } & 20-23 years old & 217 & 3.62 & 1.10 & \multirow[b]{2}{*}{-1.46} & \multirow{2}{*}{$.14^{*}$} & \multirow{2}{*}{.17} \\
\hline & 24 and older & 168 & 3.79 & 1.03 & & & \\
\hline
\end{tabular}

$* \mathrm{p}<.05$

Table 8 represented that there was no significant difference in non-compliance $(p=.49 ; p>.05)$ and overall effort ( $\mathrm{p}=.14 ; \mathrm{p}>.05)$ of students in terms of age. Cohen's $d$ was .07 for non-compliance and .17 for overall language learning effort and the effect size was really small. On the other hand, there was a significant difference in procedural, substantive and focal effort $(\mathrm{p}=.00 ; \mathrm{p}<.05)$. For procedural effort, students at the age of 24 and older $(X=3.68)$ had a higher mean score than students between the ages of 20 and $23(\mathrm{X}=3.27$ ), and thus, students at the age of 24 and older made more procedural effort than female students. Moreover, Cohen's $d$ was .48 and had a medium effect size. For substantive effort, students at the age of 24 and older $(X=3.21)$ had a higher mean score than students between the ages of 20 and $23(X=2.86)$, and thus, students at the age of 24 and older made more substantive effort than students between the ages of 20 and 23. In addition, Cohen's $d$ was .43 and had a medium effect size. For focal effort, students at the age of 24 and older $(X=4.01)$ had a higher mean score than students between the ages of 20 and $23(X=3.60)$, and thus, students at the age of 24 and older made more focal effort than students between the ages of 20 and 23. Furthermore, Cohen's $d$ was .45 and had a medium effect size.

Table 9 displayed the result of independent samples t-test to determine whether students' noncompliance, procedural, substantive, focal and overall language learning effort levels differed in terms of their education type.

Table 9. Independent samples t-test results for non-compliance, procedural, substantive, focal and overall language learning effort levels in terms of education type

\begin{tabular}{llrccccc}
\hline & Education type & $\mathrm{N}$ & $\mathrm{X}$ & $\mathrm{Sd}$ & $\mathrm{t}$ & $\mathrm{p}$ & $\begin{array}{c}\text { Effect size } \\
(\text { Cohen's } d)\end{array}$ \\
\hline \multirow{2}{*}{ Non-compliance } & Daytime & 303 & 1.45 & .77 & 1.04 & .29 & .14 \\
& Evening & 82 & 1.35 & .62 & & & \\
\hline Procedural effort & Daytime & 303 & 3.40 & .99 & -1.75 & .08 & .22 \\
\hline
\end{tabular}




\begin{tabular}{|c|c|c|c|c|c|c|c|}
\hline & Evening & 82 & 3.62 & 1.03 & & & \\
\hline \multirow{2}{*}{ Substantive effort } & Daytime & 303 & 2.98 & .84 & \multirow[b]{2}{*}{-1.43} & \multirow[b]{2}{*}{.15} & \multirow{2}{*}{.18} \\
\hline & Evening & 82 & 3.13 & .84 & & & \\
\hline \multirow{2}{*}{ Focal effort } & Daytime & 303 & 3.68 & .95 & \multirow{2}{*}{-4.09} & \multirow{2}{*}{$.00 *$} & \multirow{2}{*}{.53} \\
\hline & Evening & 82 & 4.15 & .83 & & & \\
\hline \multirow{2}{*}{ Overall effort } & Daytime & 303 & 3.67 & 1.06 & \multirow{2}{*}{-.89} & \multirow{2}{*}{.37} & \multirow{2}{*}{.11} \\
\hline & Evening & 82 & 3.79 & 1.13 & & & \\
\hline
\end{tabular}

$* \mathrm{p}<.05$

As seen in Table 9, there was no significant difference in non-compliance ( $\mathrm{p}=.29 ; \mathrm{p}>.05)$, in procedural effort ( $\mathrm{p}=.08 ; \mathrm{p}>.05)$, substantive effort ( $\mathrm{p}=.15 ; \mathrm{p}>.05)$, and overall effort $(\mathrm{p}=.37 ; \mathrm{p}>.05)$ of students in terms of education type. Cohen's $d$ values were $.14, .22, .18$ and .11 for non-compliance, procedural, substantive and overall effort, respectively and all the effect size values were small. However, there was a significant difference in focal effort $(\mathrm{p}=.00 ; \mathrm{p}<.05)$. For focal effort, students studying in the evening $(X=4.15)$ had a higher mean score than students studying in daytime $(X=3.68)$, and thus, students studying in the evening made more focal effort than students studying in daytime. In addition, Cohen's $d$ was .53 and had a medium effect size.

The results of one-way ANOVA to determine whether students' non-compliance, procedural, substantive, focal and overall language learning effort levels differed in terms of their department were shown in Table 10.

Table 10. One-way ANOVA results for non-compliance, procedural, substantive, focal and overall language learning effort levels in terms of department

\begin{tabular}{|c|c|c|c|c|c|c|c|c|}
\hline & Department & $\begin{array}{l}\text { Sum of } \\
\text { squares }\end{array}$ & df & $\begin{array}{l}\text { Mean } \\
\text { square }\end{array}$ & $\mathrm{F}$ & $\mathrm{p}$ & $\begin{array}{c}\text { Significant } \\
\text { difference } \\
\text { (Tukey) }\end{array}$ & $\begin{array}{l}\text { Effect size } \\
\text { (Cohen's } f \text { ) }\end{array}$ \\
\hline \multirow{3}{*}{$\begin{array}{l}\text { Non- } \\
\text { compliance }\end{array}$} & $\begin{array}{l}\text { Between } \\
\text { groups }\end{array}$ & 1.880 & 2 & .940 & \multirow{3}{*}{1.68} & \multirow{3}{*}{.18} & \multirow{3}{*}{---} & \multirow{3}{*}{.09} \\
\hline & Within groups & 213.836 & 382 & .560 & & & & \\
\hline & Total & 215.716 & 384 & & & & & \\
\hline \multirow{3}{*}{$\begin{array}{l}\text { Procedural } \\
\text { effort }\end{array}$} & $\begin{array}{l}\text { Between } \\
\text { groups }\end{array}$ & 4.580 & 2 & 2.290 & \multirow{3}{*}{2.27} & \multirow{3}{*}{.10} & \multirow{3}{*}{---} & \multirow{3}{*}{.11} \\
\hline & Within groups & 383.955 & 382 & 1.005 & & & & \\
\hline & Total & 388.535 & 384 & & & & & \\
\hline \multirow{3}{*}{$\begin{array}{l}\text { Substantive } \\
\text { effort }\end{array}$} & $\begin{array}{l}\text { Between } \\
\text { groups }\end{array}$ & 4.520 & 2 & 2.260 & \multirow{3}{*}{3.190} & \multirow{3}{*}{.05} & \multirow{3}{*}{---} & \multirow{3}{*}{.13} \\
\hline & Within groups & 270.634 & 382 & .708 & & & & \\
\hline & Total & 275.154 & 384 & & & & & \\
\hline \multirow{3}{*}{ Focal effort } & $\begin{array}{l}\text { Between } \\
\text { groups }\end{array}$ & 13.216 & 2 & 6.608 & \multirow{3}{*}{7.644} & \multirow{3}{*}{$.00 *$} & \multirow{3}{*}{$\begin{array}{c}\text { T.G.>G.C.A. } \\
\text { T.G>T.M. }\end{array}$} & \multirow{3}{*}{.20} \\
\hline & Within groups & 330.208 & 382 & .864 & & & & \\
\hline & Total & 343.424 & 384 & & & & & \\
\hline \multirow{3}{*}{ Overall effort } & $\begin{array}{l}\text { Between } \\
\text { groups }\end{array}$ & 19.589 & 2 & 9.794 & \multirow{3}{*}{8.773} & \multirow{3}{*}{$.00 *$} & \multirow{3}{*}{$\begin{array}{l}\text { T.G.>G.C.A. } \\
\text { G.C.A>T.M. }\end{array}$} & \multirow{3}{*}{.21} \\
\hline & Within groups & 426.470 & 382 & 1.116 & & & & \\
\hline & Total & 446.059 & 384 & & & & & \\
\hline
\end{tabular}


Table 10 indicated that there was not a significant difference in non-compliance $(p=.18 ; p>.05)$, in procedural effort $(\mathrm{p}=.10 ; \mathrm{p}>.05)$ and in substantive effort $(\mathrm{p}=.05 ; \mathrm{p}>.05)$ levels of the students in terms of their department. Cohen's $f$ values were $.09, .11$ and .13 for non-compliance, procedural, and substantive effort, respectively and all the effect size values were quite small. On the other hand, there was a significant difference in focal effort $(\mathrm{p}=.00 ; \mathrm{p}<.05)$ and overall language learning effort $(\mathrm{p}=.00$; $\mathrm{p}<.05)$. As a result of Tukey analysis for focal effort, the difference was between Tourism Guidance $(\mathrm{X}=3.93, \mathrm{Sd}=.92)$ and Gastronomy and Culinary Arts $(\mathrm{X}=3.59 ; \mathrm{Sd}=.91)$ and Tourism Management $(\mathrm{X}=3.50 ; \mathrm{Sd}=.99)$. Moreover, Cohen's $f$ was .20 , which implied that the effect size was a nearly medium. That is to say, students of Tourism Guidance made significantly more focal effort than students of Gastronomy and Culinary Arts and Tourism Management. For overall language learning effort, the difference was between Tourism Guidance $(\mathrm{X}=3.89 ; \mathrm{Sd}=1.04)$ and Gastronomy and Culinary Arts $(\mathrm{X}=3.81, \mathrm{Sd}=1.04)$; and between and Gastronomy and Culinary Arts $(\mathrm{X}=3.81, \mathrm{Sd}=1.04)$ and Tourism Management $(X=3.32 ; \mathrm{Sd}=1.09)$. In addition, Cohen's $f$ was .21 and the effect size was almost medium. In other words, in general, students of Tourism Guidance made significantly more effort than students of Gastronomy and Culinary Arts and Tourism Management.

The result of one-way ANOVA to determine whether students' non-compliance, procedural, substantive, focal and overall language learning effort levels differed in terms of their achievement was displayed in Table 11.

Table 11. One-way ANOVA results for non-compliance, procedural, substantive, focal and overall language learning effort levels in terms of achievement

\begin{tabular}{|c|c|c|c|c|c|c|c|c|}
\hline & Achievement & $\begin{array}{l}\text { Sum of } \\
\text { squares }\end{array}$ & df & $\begin{array}{l}\text { Mean } \\
\text { square }\end{array}$ & $\mathrm{F}$ & $\mathrm{p}$ & $\begin{array}{c}\text { Significant } \\
\text { difference } \\
\text { (Tukey) }\end{array}$ & $\begin{array}{l}\text { Effect size } \\
\text { (Cohen's } f \text { ) }\end{array}$ \\
\hline \multirow{3}{*}{$\begin{array}{l}\text { Non- } \\
\text { compliance }\end{array}$} & $\begin{array}{l}\text { Between } \\
\text { groups }\end{array}$ & 9.144 & 2 & 4.572 & \multirow{3}{*}{8.455} & \multirow{3}{*}{$.00 *$} & \multirow{3}{*}{$\begin{array}{l}1>2 \\
1>3\end{array}$} & \multirow{3}{*}{.21} \\
\hline & Within groups & 206.572 & 382 & .541 & & & & \\
\hline & Total & 215.716 & 384 & & & & & \\
\hline \multirow{3}{*}{$\begin{array}{l}\text { Procedural } \\
\text { effort }\end{array}$} & $\begin{array}{l}\text { Between } \\
\text { groups }\end{array}$ & 35.686 & 2 & 17.843 & \multirow{3}{*}{19.317} & \multirow{3}{*}{$.00 *$} & \multirow{3}{*}{$\begin{array}{l}2>1 \\
3>1 \\
3>2\end{array}$} & \multirow{3}{*}{.32} \\
\hline & Within groups & 352.849 & 382 & .924 & & & & \\
\hline & Total & 388.535 & 384 & & & & & \\
\hline \multirow{3}{*}{$\begin{array}{l}\text { Substantive } \\
\text { effort }\end{array}$} & $\begin{array}{l}\text { Between } \\
\text { groups }\end{array}$ & 26.995 & 2 & 13.497 & \multirow{3}{*}{20.777} & \multirow{3}{*}{$.00 *$} & \multirow{3}{*}{$\begin{array}{l}3>1 \\
3>2\end{array}$} & \multirow{3}{*}{.33} \\
\hline & Within groups & 248.159 & 382 & .650 & & & & \\
\hline & Total & 275.154 & 384 & & & & & \\
\hline \multirow{3}{*}{ Focal effort } & $\begin{array}{l}\text { Between } \\
\text { groups }\end{array}$ & 14.737 & 2 & 7.368 & \multirow{3}{*}{8.564} & \multirow{3}{*}{$.00 *$} & \multirow{3}{*}{$\begin{array}{l}3>1 \\
3>2\end{array}$} & \multirow{3}{*}{.21} \\
\hline & Within groups & 328.687 & 382 & .860 & & & & \\
\hline & Total & 343.424 & 384 & & & & & \\
\hline \multirow{3}{*}{ Overall effort } & $\begin{array}{l}\text { Between } \\
\text { groups }\end{array}$ & 49.356 & 2 & 24.678 & \multirow{3}{*}{23.763} & \multirow{3}{*}{$.00 *$} & \multirow{3}{*}{$\begin{array}{l}3>2 \\
3>1\end{array}$} & \multirow{3}{*}{.35} \\
\hline & Within groups & 396.703 & 382 & 1.038 & & & & \\
\hline & Total & 446.059 & 384 & & & & & \\
\hline
\end{tabular}

As indicated in Table 11, there was a significant difference in non-compliance $(\mathrm{p}=.00 ; \mathrm{p}<.05)$, procedural $(\mathrm{p}=.00 ; \mathrm{p}<.05)$, substantive $(\mathrm{p}=.00 ; \mathrm{p}<.05)$, focal $(\mathrm{p}=.00 ; \mathrm{p}<.05)$ and overall language 
learning effort $(\mathrm{p}=.00 ; \mathrm{p}<.05)$ levels of the students in terms of their achievement. As a result of Tukey analysis for non-compliance, the difference was between students with low achievement $(X=1.82$; $\mathrm{Sd}=.94)$ and those with mid achievement $(\mathrm{X}=1.42 ; \mathrm{Sd}=.74)$ and those with high achievement $(\mathrm{X}=1.24$; $\mathrm{Sd}=.55)$. Cohen's $f$ was .21 and the effect size was nearly medium. For procedural effort, the difference was between students with low achievement $(X=2.97 ; \mathrm{Sd}=.75)$ and those with mid achievement $(X=3.36 ; \mathrm{Sd}=1.03)$ and those with high achievement $(\mathrm{X}=4.01 ; \mathrm{Sd}=.78)$. In addition, there was a difference between students with mid achievement $(X=3.36$; $\mathrm{Sd}=1.03)$ and those with high achievement $(\mathrm{X}=4.01 ; \mathrm{Sd}=.78)$. Cohen's $f$ was .32 , which implied a medium effect size. For substantive effort, the difference was between students with high achievement $(\mathrm{X}=3.53 ; \mathrm{Sd}=.70)$ and those with mid achievement $(X=2.92 ; \mathrm{Sd}=.86)$ and those with low achievement $(\mathrm{X}=2.69 ; \mathrm{Sd}=.53)$. Cohen's $f$ was .33, which implied a medium effect size. For focal effort, the difference was between students with high achievement $(X=4.17 ; \mathrm{Sd}=.69)$ and those with mid achievement $(X=3.70 ; \mathrm{Sd}=.97)$ and those with low achievement $(X=3.59 ; \mathrm{Sd}=.98)$. Cohen's $f$ was .21 and the effect size was almost medium. Similarly, for overall language learning effort, the difference was between students with high achievement $(X=4.71$; $\mathrm{Sd}=.62)$ and those with mid achievement $(X=3.59 ; \mathrm{Sd}=1.06)$ and those with low achievement $(X=3.52$; $\mathrm{Sd}=1.03$ ). Cohen's $f$ was .35 , which implied a nearly large effect size. It can be inferred from the findings that students with high achievement made more procedural, substantive, focal and overall language learning effort and showed less non-compliance than those with lower achievement.

\section{Discussion}

The study aimed at investigating foreign language learning effort levels of students in English for Specific Purposes. The participants of the study included 385 students studying at a faculty of tourism and taking vocational English course at a state university in Turkey. Foreign language learning effort levels of students were examined in terms of four sub-dimensions (non-compliance, procedural, substantive, focal) and overall effort.

The findings of the study revealed that the students' mean score for non-compliance was 1.43 and it was at "never" level. The students declared that they never engage in disruptive behaviors in classes, cheat on exams and plagiarize their homework assignments. Their mean score for procedural effort was 3.45 and it was at "often" level. The students expressed that they sometimes do their homework on time. They also reported that they often submit their homework on time and carry out the assigned in-class tasks. Their mean score for substantive effort was 3.01 and it was at "sometimes" level. The students stated that they often prepare well for their foreign language exams, revise their assignments if they receive any corrections and consult their foreign language instructor or other experts for advice on how to improve their English. They reported that they sometimes review the topics covered in their foreign language class, practice from various sources even if they are not given a homework assignment, engage in foreign language mediums in out-of-class activities (e.g. read books, watch movies, speak to foreigners, etc.). They also expressed that they rarely review the topics to be covered in their class and volunteer for extra homework assignments if possible. Their mean score for focal effort was 3.78 and it was at "often" level. The students stated that they often attentively listen to their instructor, attentively listen to the contributions made by their peers and concentrate solely on the lesson in their classes. Finally, their mean score for overall effort was 3.69 and it was at "often" level.

As for gender differences, there was no significant difference in the students' non-compliance and overall effort levels but female students had had a higher mean score than male students. However, in a study in Taiwan revealed that male students exhibit more effort than female students in business English (Hsu, 2005). The findings revealed that there was a significant difference in procedural, substantive and 
focal effort in terms of gender. Female students made more procedural, substantive and focal effort than male students. For procedural effort, female students rather than male students do their homework on time, submit their homework on time and carry out the assigned in-class tasks. Similarly, studies carried out in Canada found out that girls spent more time to study and do homework than boys for science (Adamuti-Trache \& Sweet, 2013) and all subject areas (McMullen, 2004). For substantive effort, female students more than male students prepare well for their foreign language exams, revise their assignments if they receive any corrections and consult their foreign language instructor or other experts for advice on how to improve their English, review the topics covered in their foreign language class, practice from various sources even if they are not given a homework assignment, engage in foreign language mediums in out-of-class activities (e.g. read books, watch movies, speak to foreigners, etc.), review the topics to be covered in their class and volunteer for extra homework assignments if possible. In the same vein, girls approve the value of academic effort and attach academic success with effort more than boys (Adamuti-Trache \& Sweet, 2013; Yeung, 2011) and female students had higher trait and state effort than their male counterparts (Awang-Hashim, O’Neil \& Hocevar, 2002). For focal effort, female students rather male students attentively listen to their instructor, attentively listen to the contributions made by their peers and concentrate solely on the lesson in their classes. According to Connelly (2008) and Kelly (2008), girls often get higher grades than boys in classes. They also argue that teachers generally take student classroom behavior into consideration in grading and boys usually exhibit disruptive behaviors and they are less compliant than girls in the classroom. Thus, the finding of the study is consistent with previous studies.

Another finding of the study was that there was no significant difference in non-compliance and overall effort of students in terms of age. On the other hand, there was a significant difference in procedural, substantive and focal effort. For procedural, substantive and focal effort, students at the age of 24 and older had a higher mean score than students between the ages of 20 and 23, and thus, students at the age of 24 and older made more procedural, substantive and focal effort than students between the ages of 20 and 23. Thus, these findings can be regarded that when students get older their learning effort increase. Similarly, in Carbonaro (2005)'s study with 8th and 10th grade students, he found out that the higher the students' tracks are, the more effort they exert. In addition, Al Shaye et al. (2014) revealed in their study with Saudi female students learning English that 12th graders put forth more effort than 9th graders. On the other hand, Genç (2016) carried out a study with students studying English at preparatory classes at tertiary education in Turkey and found out no relationship between age and effort in attributions to success and failure.

When education type was taken into consideration, it was revealed in the study that there was no significant difference in non-compliance, procedural, substantive and overall effort of students. However, there was a significant difference in focal effort in terms of education type. For focal effort, students studying in the evening had a higher mean score than students studying in daytime, and thus, students studying in the evening listen to the instructor and the contributions made by their peers more attentively and they concentrate solely on the lesson in the classes more than students studying in daytime. The finding of the study may have resulted from the fact that students studying in the evening were usually working. The students may have wanted to benefit from the advantages provided by the course to be able to use what they have learned.

As for students' departments, there was not a significant difference in non-compliance, procedural and substantive effort levels of the students. On the other hand, there was a significant difference in focal effort and overall language learning effort. The difference in focal effort was between Tourism Guidance and Gastronomy and Culinary Arts and Tourism Management. In other words, students of Tourism Guidance listen to the instructor and the contributions made by their peers more attentively and they concentrate solely on the lesson in the classes more than students of Gastronomy and Culinary Arts 
and Tourism Management. For overall language learning effort, the difference was between Tourism Guidance and Gastronomy and Culinary Arts and between Gastronomy and Culinary Arts and Tourism Management. The finding can be considered that students of Tourism Guidance made significantly more effort than students of Gastronomy and Culinary Arts and Tourism Management. Students of Tourism Guidance will always be with tourists and have to talk in English when they start working as a guide. Hence, they want to do their best in their profession. The finding may be the result of this fact. In addition, Li (2012) and Hemmings and Kay (2010) reached a conclusion that attitude predicted effort. Özer (2019a) found out that attitudes of students in vocational English course differed and the difference was between Tourism Management and Tourism Guidance and Gastronomy and Culinary Arts in favor of Tourism Guidance and Gastronomy and Culinary Arts. Another study revealed that students of Tourism Guidance had the highest levels of attitude towards vocational English among other tourism departments (Özer \& Y1lmaz, 2016). Therefore, the finding of the study favored previous studies in the literature.

Another focus of the study was to compare and contrast whether there was a significant difference in non-compliance, procedural, substantive, focal and overall language learning effort levels of the students in terms of their achievement. The difference in non-compliance was between students with low achievement and those with mid achievement and those with high achievement. It can be inferred from this finding that students with non-compliant behaviors (engaging in disruptive behaviors in classes, cheating on exams and/or plagiarizing homework assignments) are more likely to get low scores and achieve less. For procedural effort, the difference was between students with low achievement and those with mid achievement and those with high achievement. In addition, there was a difference between students with mid achievement and those with high achievement. In other words, carrying out the assigned in-class tasks, doing and submitting homework on time enable students to get higher scores in exams. For substantive effort, the difference was between students with high achievement and those with mid achievement and those with low achievement. Preparing well for exams, reviewing the topics covered and to be covered, practicing from various sources, reading books, watching movies, speaking to foreigners as out-of-class activities, revising assignments if received any corrections, consulting for advice on how to improve English and volunteering for extra homework assignments assist students to engage in English (the foreign language) continuously which results in high achievement in exams. For focal effort, the difference was between students with high achievement and those with mid achievement and those with low achievement. Listening to the instructor or peers attentively and concentrating solely on the lesson in classes, that's to say, keeping themselves from distractors lead students to achieve more.

For overall language learning effort, the difference was between students with high achievement and those with mid achievement and those with low achievement. The findings suggested that students with high achievement made more procedural, substantive, focal and overall language learning effort and exerted less non-compliant behaviors than those with lower achievement. The finding of the study is in parallel with previous studies in the literature (Phan, 2008; Opare \& Dramanu, 2002). In their studies with high school students, Twum Ampofo and Osei-Owusu (2015a, 2015b) in Ghana and Aratibel and Bueno-Alastuey (2015) in Spain revealed positive correlations between learning effort and English achievement. Inagaki (2014) with undergraduate students studying English in Japan asserted that when students expended more effort, they got higher academic outcomes. Moreover, in many studies it was found out that effort predicted learning and academic performance (Cole, Bergin \& Whittaker, 2008; Carbonaro, 2005; Pintrich, 2004; Awang-Hashim, O’Neil \& Hocevar, 2002). 


\section{Conclusions}

The current study concluded that students' level of non-compliance was at "never" level, their procedural, focal and overall effort levels were at "often" level and their substantive effort level was at "sometimes" level. There was no significant difference in non-compliance and overall effort levels of the students; however, there was a significant difference in their procedural, substantive and focal effort levels in terms of their gender and age in favor of female and older students. There was no significant difference in non-compliance, procedural, substantive and overall effort levels of the students but there was a significant difference in their focal effort levels in terms of their education type in favor of students studying in the evening. There was no significant difference in non-compliance, procedural and substantive effort levels of the students; nevertheless, there was a significant difference in their focal and overall language learning effort levels in terms of their department and students of Tourism Guidance had the highest level of effort. There was a significant difference in non-compliance, procedural, substantive, focal and overall language learning effort levels of the students in terms of their achievement. Students with high achievement exerted more procedural, substantive, focal and overall language learning effort and less non-compliant behaviors than those with lower achievement.

The results of the current research have noteworthy implications for researchers and students. Male and younger students exert less procedural, substantive and focal effort so the reason why they put forth less effort may be examined in a qualitative study. Students of Tourism Management and Gastronomy and Culinary Arts exhibit less effort. As Hsu (2005) concluded that students' motivation and attitude significantly correlated with effort, attitude and motivation levels of students of Tourism Management and Gastronomy and Culinary Arts should be increased. Students with less achievement exert less procedural, substantive, focal and overall language learning effort and more non-compliance therefore students with low achievement may be informed/reminded by instructors of English that the more effort they exert the higher grades they will get. The findings of the study may shed lights on the literature.

The research has some limitations. First, it is limited to the instrument used in the study. Second, it is limited to students at a faculty of tourism and taking vocational English course. For further studies, effort levels of students taking vocational English course at different faculties or studying in preparatory classes at school of foreign languages at tertiary education may be investigated and compared with the findings of the present study. Last but not least, the relationship between other variables affecting teaching English such as attitude, motivation, anxiety, self-efficacy and goal orientations and foreign language learning effort may be analysed at tertiary education.

\section{Ethics Committee Approval}

The author(s) confirm(s) that the study does not need ethics committee approval according to the research integrity rules in their country (Date of Confirmation: April 30, 2020).

\section{References}

Adamuti-Trache, M., \& Sweet, R. (2013). Academic effort and achievement in science: Beyond a gendered relationship. Research in Science Education, 43, 2367-2385.

Agbuga, B., \& Xiang, P. (2008). Achievement goals and their relations to self-reported persistence/effort in secondary physical education: A trichotomous achievement goal framework. Journal of Teaching in Physical Education, 27(2), 179-191. 
Al Shaye, R., Yeung, A. S., \& Suliman, R. (2014). Saudi female students learning English: Motivation, effort, and anxiety. The International Journal of Learner Diversity and Identities, 20(4), 1-13.

Aratibel, A. P., \& Bueno-Alastuey, C. (2015). The influence of socio-economic background, personal effort and motivation on English proficiency. Huarte de San Juan. Filología y Didáctica de la Lengua, 15, 43-65.

Awang-Hashim, R., O'Neil, H. F. \& Hocevar, D. (2002). Ethnicity, effort, self-efficacy, worry, and statistics achievement in Malaysia: A construct validation of the state-trait motivation model. Educational Assessment, 8, 341-364.

Bozick, R. N., \& Dempsey T. L. (2010). Effort. In Rosen, J. A., Glennie, E. J., Dalton, B. W., Lennon, J. M. \& R. N., Bozick (Eds.), Noncognitive skills in the classroom: New perspectives on educational research (pp. 39-68). Research Triangle Park, NC: RTI International.

Carbonaro, W. (2005). Tracking, student effort, and academic achievement. Sociology of Education, 78, 27-49.

Cohen, J. (1988). Statistical power analysis for the behavioral sciences (2nd ed.). Hillsdale, NJ: Erlbaum.

Cole, J. S., Bergin, D. A., \& Whittaker, T. A. (2008). Predicting student achievement for low stakes tests with effort and task value. Contemporary Educational Psychology, 33, 609-624.

Connelly, P. (2008). A critical review of some recent developments in quantitative research on gender and achievement in the United Kingdom. British Journal of Sociology of Education, 29(3), 249-260.

Çavuşoğlu Deveci, C., Arslan Buyruk, A., Erdoğan, P. ve Yücel Toy, B. (2016). İngilizce konuşma becerisinin öğretimine ilişkin ihtiyaçların değerlendirilmesi. Turkish Studies-International Periodical for the Languages, Literature and History of Turkish or Turkic, 11(14), 915-934.

Didia, D., \& Hasnat, B. (1998). The determinants of performance in the university introductory finance course. Financial Practice and Education, 8(1), 102-107.

Dörnyei, Z. (2005). The psychology of the language learner: Individual differences in second language acquisition. Mahwah, NJ: Lawrence Erlbaum.

Evin Gencel, İ. ve Satmaz, İ (2017). Öğretmen adaylarının üstün yetenekli öğrencilerin eğitimine yönelik tutumları. Uluslararası Eğitim Programları ve Öğretim Çalışmaları Dergisi, 7(14), 49-61.

Genç, G. (2016). Attributions to success and failure in English language learning: The effects of gender, age and perceived success. European Journal of Education Studies, 2(12), 25-43.

Hemmings, B., \& Kay, R. (2010). Prior achievement, effort, and mathematics attitude as predictors of current achievement. The Australian Educational Researcher, 37(2),41-58.

Hsu, S. (2005). Business English learning motivation and effort on proficiency among junior college students. Nanya Education Report, 25, 119-131.

Inagaki, Y. (2014, March). A mediator between motives and learning effort: The role of acquisition goals in motivational process of foreign language learners. Paper presented at the Global Summit on Education GSE, Kuala Lumpur, Malaysia. Retrieved from https://worldconferences.net/proceedings/gse2014/toc/papers_gse2014/G\%20156\%20\%20YOSHINORI\%20INAGAKI_A\%20MEDIATOR\%20BETWEEN\%20MOTIVES\%20AND\% 20LEARNING\%20EFFORT_read.pdf 
Işık, İ. (2014). Yokluk hipotezi anlamlılık testi ve etki büyüklügü tartışmalarının psikoloji araştırmalarına yansıması. Eleştirel Psikoloji Bülteni, 5, 55-80.

Karabiyık, C., \& Mirici, İ. H. (2018). Development and validation of the foreign language learning effort scale for Turkish tertiary-level students. Educational Sciences: Theory \& Practice, 18, 373-395. http://dx.doi.org/10.12738/estp.2018.2.0010.

Karasar, N. (2003). Bilimsel araştırma yöntemleri. (12nd ed.). Ankara: Nobel Yayın Dağıtım.

Kelly, S. (2008). What types of student effort are rewarded with high marks? Sociology of Education, $81(1), 32-52$.

Kotrlik, J. W., \& Williams, H. A. (2003). The incorporation of effect size in information technology, learning, and performance research. Information Technology, Learning, and Performance Journal, 2l(1), 1-7.

Li, L. K. Y. (2012). A study of the attitude, self-efficacy, effort and academic achievement of CityU students towards research methods and statistics. Discovery-SS Student E-Journal, 1, 154-183.

McMullen, K. (2004). The gap in achievement between boys and girls. Education Matters, 4. Ottawa: Statistics Canada. http://www.statcan.gc.ca/pub/81-004-x/200410/7423-eng.htm.

Opare, J. A., \& Dramanu, B. Y. (2002). Students' academic performance: Academic effort as an intervening variable. IFE PsychologIA, 10(2), 136-148.

Özer, S. (2019a). An investigation of attitude, motivation and anxiety levels of students studying at a faculty of tourism towards vocational English course. Journal of Language and Linguistic Studies, 15(2), 560-577. Doi: 10.17263/jlls.586246.

Özer, S. (2019b). Self-efficacy perceptions of vocational students about cognitive objectives of English language course. Maarif Mektepleri International Journal of Educational Sciences, 3(2), 1-16.

Özer, S., \& Yılmaz, E. (2016). Students' attitudes towards vocational foreign language course. International Journal of Contemporary Educational Research, 3(2), 55-64.

Özsoy, S., \& Özsoy, G. (2013). Eğitim araştırmalarında etki büyüklüğü raporlanması. İlköğretim Online, 12(2), 334-346.

Phan, H. P. (2008). Exploring students' reflective thinking practice, processing strategies, efforts and achievement goal-orientation. Educational Psychology, 29(3), 297-313.

Pintrich, P. R. (2004). A conceptual framework for assessing motivation and self-regulated learning in college students. Educational Psychology Review, 16, 385-407.

Tekin, H. (2002). Eğitimde ölçme ve değerlendirme. Ankara: Yargı Yayınc1lık.

Twum Ampofo, E., \& Osei-Owusu, B. (2015a). Determinants of academic performance among senior high school (SHS) students in the Ashanti Mampong municipality of Ghana. International Journal of Academic Research and Reflection, 3(3), 33-48.

Twum Ampofo, E., \& Osei-Owusu, B. (2015b). Students' academic performance as mediated by students' academic ambition and effort in the public senior high schools in Ashanti Mampong Municipality of Ghana. International Journal of Academic Research and Reflection, 3(5), 19-35.

Yeung, A. S. (2011). Student self-concept and effort: gender and grade differences. Educational Psychology, 31(6), 749-772. 
Yeung, A. S., \& McInerney, D.M. (2005). Students' school motivation and aspiration over high school years. Educational Psychology, 25, 537-554.

Zimmerman, B. J., \& Risenberg, R. (1997). Self-regulatory dimensions of academic learning and motivation. In G. Phye (Ed), Handbook of academic learning (pp. 105-125). New York: Academic Press.

\section{Özel amaçlı İngilizcede yabancı dil öğrenme çabası}

\section{$\ddot{O} z$}

Bu çalışma, öğrencilerin Özel Amaçlı İngilizceye yönelik yabancı dil öğrenme çaba düzeylerini incelemeyi amaçlamaktadır. Araştırmada nicel araştırma yöntemi ve tarama modeli kullanılmıştır. Araştırmaya bir devlet üniversitesinin turizm fakültesinde öğrenim gören ve mesleki İngilizce dersini alan 385 öğrenci gönüllü olarak katılmıştır. Araştırmada veri toplamak amacıyla Yabancı Dil Öğrenme Çabası Ölçeği (YDÖÇÖ) kullanılmıştır. Araştırma bulguları, öğrencilerin yabancı dil öğrenme çabasının uyumama boyutu ortalamalarının "asla" düzeyinde; yöntemsel/biçimsel ve odaksal çaba boyutları ile genel çaba ortalamalarını "sık sık" düzeyinde ve devamlı çaba boyutu ortalamalarının "bazen" düzeyinde olduğu belirlenmiştir. Cinsiyet ve yaş değişkenine göre, öğrencilerin uymama boyutu ve genel çaba düzeylerinin anlamlı bir farkl1lık göstermediği, ancak yöntemsel/biçimsel, odaksal ve devamlı çaba düzeylerinin anlamlı bir farklılık gösterdiği tespit edilmiştir. Öğrenim türü değişkenine göre, öğrencilerin uymama, yöntemsel/biçimsel, devamlı ve genel çaba düzeylerinde anlamlı bir fark bulunmamakla birlikte, odaksal çaba düzeylerinde anlamlı bir fark bulunmuştur. Bölüm değişkenine göre, öğrencilerin uymama, yöntemsel/biçimsel ve devamlı çaba düzeylerinin anlamlı bir farklılık göstermediği, fakat odaksal ve genel çaba düzeylerinin anlamlı bir farklılık gösterdiği görülmüştür. Başarı değişkenine göre, öğrencilerin uymama, yöntemsel/biçimsel, devamlı, odaksal ve genel çaba düzeyleri arasında anlamlı bir fark olduğu anlaşılmıştır.

Anahtar sözcükler: yabancı dil öğrenme çabası; Özel Amaçlı İngilizce; mesleki İngilizce dersi; turizm

\section{AUTHOR BIODATA}

Dr. Selda Özer majored in English Language Teaching and got her B.A. degree from Hacettepe University. She received her M.A. degree in Curriculum and Instruction from Erciyes University and her PhD degree in Curriculum and Instruction from Necmettin Erbakan University. She is currently a lecturer and teaches English at School of Foreign Languages, Nevsehir Hacı Bektaş Veli University, Turkey. She worked as a teacher of English at a governmental primary school in Ankara from 2002 to 2004. She is interested in curriculum and instruction, English language teaching, specifically teaching vocational English. 